Critical Discourse Analysis and Identity: Why Bother?

by

Susan Ainsworth

Work and Organisational Studies

University of Sydney

NSW 2006

Australia

Tel: +61-2-9036-5304

Fax: +61-2-9351 4729

Email: s.ainsworth@econ.usyd.edu.au

and

Cynthia Hardy

Department of Management

University of Melbourne

Parkville

Victoria 3010

Australia

Tel: +61-3-8344-3719

Fax: +61-3-8344-3731

Email: chardy@unimelb.edu.au 
Address for proofs and offprints:

Susan Ainsworth

Work and Organisational Studies

University of Sydney

NSW 2006

Australia

Tel: +61-2-9036-5304

Fax: +61-2-9351 4729

Email: s.ainsworth@econ.usyd.edu.au

\section{Size}

9,729 words 


\section{Author biographies}

Susan Ainsworth is currently a lecturer in Work and Organisational Studies at the University of Sydney. Her research interests include gender and employment, older workers, critical organization studies, discourse analysis, the social construction of identity, the impact of information and communication technologies on work and organizations, and public policy. She has published in Organization Studies (2003), Gender, Work \& Organization (2002), and Tamara: Journal of Critical Postmodern Organization Science (2001) and has a joint chapter (with Cynthia Hardy) on discourse and identity in the forthcoming Sage Handbook on Organizational Discourse Analysis (2004).

Cynthia Hardy has been Professor of Management at the University of Melbourne since 1998. Previously, she was a professor in the Faculty of Management at McGill University in Canada. Her main research interests revolve around the study of power and politics in organizations, organizational discourse theory and critical discourse analysis, and she is particularly interested in how power and politics occur within a larger discursive context. She recently published Discourse Analysis: Investigating Processes of Social Construction with Nelson Phillips, as well as co-editing a special issue of Organization Studies on organizational discourse and the Sage Handbook of Organizational Discourse. In total, she has published twelve books and edited volumes, including the Handbook of Organization Studies, published by Sage, which won the George R. Terry Book Award at the 1997Academy of Management. She has written over 60 journal articles and book chapters, and her work has appeared in many leading international journals, including the Academy of Management Journal, Organization Studies, Journal of Management Studies, Human Relations, Organization Science, and California Management. 


\title{
Critical Discourse Analysis and Identity: Why Bother?
}

\begin{abstract}
Critical discourse analysis (CDA) and other forms of discourse analysis are regularly used to study identity, but rarely do researchers systematically compare and contrast them with other theories to identify exactly what a discursive approach contributes. In this paper, we take the example of a particular identity - the older worker - and systematically compare the contribution of CDA with other approaches, including economics, labour market research, gerontology and cultural studies. In so doing, we show the kinds of research questions that CDA can address, which other theories grappling with identity cannot. In this way, we hope to delineate more clearly what CDA is, to identify specifically how it contributes to the study of identity, and to show what it can do, compared to other theories.
\end{abstract}

Keywords: critical discourse analysis, identity, older workers, social construction 


\section{Introduction}

In this paper, we demonstrate the value of adopting Critical discourse analysis (CDA) to study identity. We take the example of a particular identity that has attracted increasing interest among researchers, policy makers and the media - older workers - to illustrate the potential contribution that CDA can make to our understanding of the processes of identity construction and its effects. To this end, we review and discuss research on older workers from a variety of disciplines (economics, labour market research, gerontology and cultural studies) and systematically compare their orientation, emphases and findings. We argue that while such disciplines have made valuable contributions to knowledge, key gaps remain that can be addressed using CDA. While CDA and other forms of discourse analysis are regularly used to study identity, rarely have researchers systematically compared and contrasted them with other theories to identify exactly what a discursive approach contributes. Our contribution then is to show, rather than assume, that CDA represents a valuable way of approaching the study of identity.

We selected the identity of the older worker for three related reasons. Firstly it has received much public, academic and government attention due to aging populations and persistent unemployment among older workers in developed economies. For example, governments in many industrialized countries are concerned with the economic and budgetary consequences of population aging, especially as expectations about the role of the state in providing for people in older age are changing. This has been accompanied by a trend where older men, in particular, exit early from employment, as a result of organizational downsizing, industry restructuring and economic recession. Older workers face significant barriers attempting to re-enter the labour market, including skill obsolescence, changes in the industrial structure of the economy and age discrimination. In addition, some sections of the older population, such as the older unemployed ${ }^{1}$ are economically and socially disadvantaged. 
While research on older workers has been focused almost exclusively on the work and retirement patterns of older male workers, more recent research has attempted to redress this gap by examining, for example, the different issues facing older women and different cultural groups in the labour market.

The second reason we selected older workers was because research, public commentary and policy consistently featured the construction of ageing and older workers as 'problematic' (Correll 1999) and a current or potential burden on the rest of society (e.g. Pickard 1999), symptomatic of a 'new ageism’ (Butler 1989). Representations of population ageing were typically accompanied by arguments that it will lead to economic decline, financial strain on health care and social security systems, and social problems, etc., which Clark (1993) has characterized as ‘apocalyptic demography’. Moreover, these representations persist despite research that has challenged many of the common, negative stereotypes about older workers.

Thirdly, there was a noticeable lack of clarity about the category of 'older workers' itself. Threshold chronological ages for inclusion in the category of older worker range from 40 to 65 years (Ainsworth 2003), and consequently, there is little agreement and clarity about who is an 'older worker'. Instead of assuming the category of the 'older worker' as an object of research, CDA can assist in purposefully unpacking this notion by providing ways to understand and examine how social identity is constructed, as well as the effects of such identity construction.

In this paper, we examine research from economics, labour market studies, gerontology, and cultural studies in order to illustrate their contributions to knowledge about older workers, and the potential contribution of CDA. Economic research tends to explore the influence of economic and financial factors on individual decisions (e.g., the decision to retire) and on policy decisions (such as the financial implications of state-funded health care 
and pensions). Labour market research focuses on labour force participation and unemployment. Gerontology adopts a biomedical perspective, and has been heavily influenced by psychology and health related research. Cultural studies approaches aging and older workers from a social and cultural perspective. While these different fields of research contribute to our understanding of these issues, they fail to address more fundamental questions concerning the very concept of the “older worker”. As we argue, CDA is one approach that is well suited to addressing these more fundamental questions.

The structure of this paper is as follows. We first present an overview of the different bodies of research on the older worker, drawing some conclusions regarding both the contributions and the limitations of this work. We then introduce CDA, showing how it has been used to study identity and how it could contribute to studying older workers. Finally, we discuss the implications of using CDA for future research, as well as for government policy and organizational practice.

\section{The Study of the Older Worker}

Older workers constitute a growing proportion of many workforces and populations. The International Labor Organization estimates that, by 2025, 32 per cent of the European population and 30 per cent of the population in North America will be over 55 years (Ilmarinen 2001). In 2000, the median age of a worker in the United States was 40 years, the age at which they are considered to be an older worker under the Age Discrimination and Employment Act (McMahan and Phillips 2000). The proportion of the Japanese population over 65 years is currently 20 percent and is expected to increase to 29 per cent by 2025 (Pearson 2003). In Australia, forecasts project that by 2021 more than 20 per cent of the population will be over 65 years (Encel 2003). These demographics have resulted in perceptions of an economically dependent older population that is a burden on the younger, productive members of society and fuelled debate about the future of the welfare state (Butler 
1989; Laczko and Phillipson 1991; Ginn and Arber 1995). Accordingly, we hear of “apocalyptic” demographic projections of population aging (Clark 1993) and claims of “a looming old age crisis” (Saunders 1996), although Saunders argues that this aging crisis is more accurately described as a “crisis of governance” as governments struggle to respond.

Such demographics have led researchers to focus attention on older workers and the accompanying changes in key social institutions that have radically altered previously clear patterns around sequential phases of education, full-time work, and full-time retirement. Older workers also attract research interest because of disadvantages they face. For example, age discrimination hinders their recruitment and training, as well as targeting them for downsizing and early retirement. Once they become unemployed, older people experience much longer average rates of joblessness than other groups (Council on the Ageing 1992, 1999; VandenHeuvel 1999). Many older workers also face periods of unemployment following early exit from the workforce, part-time or casual work, or transition jobs that are unrelated to previous occupation (Doeringer 1990; Laczko and Phillipson 1991). In this section, we

explore research from economics, labour market research, gerontology and cultural studies. ${ }^{2}$

\section{Economics}

Economics uses a variety of quantitative techniques to explain the costs of aging, productivity patterns, retirement decisions, and to provide models that explain the employment patterns experienced by older workers.

First, dependency ratios - "the ratio of the part of the population which is productively employed to the part which is dependent” (Levine 1988: 52) - have been used to support the view that a crisis is looming for mature economies where the economic burden placed on the younger working population by the older age group will be intolerable (Ginn and Arber 1995; Saunders 1996). This view dominates policy debates, despite criticisms that dependency ratios are "overly normative" and "convey the impression that old age is always and only a 
period of dependency on others, rather than a period in which it is possible to make a continued positive contribution to many aspects of economic and social life” (Saunders 1996: 10; also see Blondal and Scarpetta 1998; Butler 1989; Bytheway 1995; Laczko and Phillipson 1991).

Second, economists have also studied the relationship between an aging workforce and productivity. This research tends to argue that as the workforce ages, productivity falls (e.g., Blondal and Scarpetta 1998; Hutchens 1993), although other research has challenged these findings. For example, using cross-industry comparisons, Barnes et al. (1999) found no clear relationship between chronological age and productivity and some high productivity growth industries had larger proportions of older workers and fewer younger workers.

A third stream of research focuses on the effects of pensions and income on retirement decisions (Dahl, Nilsen and Vaage 2000; Doeringer 1990; Doeringer and Terkla 1990). It explores the potential effects of pension policy on decisions to retire (e.g., Latulippe and Turner 2000; Purcell 2000), the interaction of different social security provisions with labour market participation (e.g., Baker 2002; Choi 2000), and the effects of pension provisions on early retirement (Baker and Benjamin 1999; Blondal and Scarpetta 1998). This research assumes that individuals have freedom of choice to maximize economic benefits (Hutchens 1993), although evidence from other fields suggests that early exit from the workforce by older workers is often involuntary. It also tends to focus on white males, ignoring women whose discontinuous work histories make them more difficult to study (Ginn and Arber 1996; Rein and Jacobs 1993), as well as members of different ethnic groups and socioeconomic classes (Dahl et al.2000; Doeringer 1990; Ginn and Arber 1996; Laczko and Phillipson 1991; Levine 1988; McCallum 1992; Patrickson and Hartmann 1996; Ruhm 1990).

Finally, a variety of economic theories have been used to explain the behaviour of employers and employees. The deferred compensation model (Agarwal and DeGroote 1998; 
Heywood, Ho and Wei 1999; Lazer 1979; Levine 1988; Reid 1996) postulates that employees are paid less than their marginal product early in their careers, and more later on: compulsory retirement stops this escalation in compensation. Despite challenges (e.g., Agarwal and deGroote 1998; Levine 1988; Mallier and Morris 2003), it provides an economically based rational explanation for employer behaviour, such as passing over older workers for promotion (e.g., Adams 2002) and targeting older workers for early exit from the workforce. The job-rationing model associated with Furstenberg and Thrall (Levine 1988) explains why older people occupy a marginal position in the labour market: a cultural queuing mechanism means that less attractive groups wait in line for employment. The demand for older workers thus depends on how far down the queue employers have to look to find an adequate labour supply. This theory does not, however, explain how older workers come to comprise a marginal group in the first place (Levine 1988). Theories of the return on training investment link discrimination against older workers in accessing training (Frerichs and Naegele 1997; Johnson and Zimmerman 1993; Schrank and Waring 1989) to assumptions about their willingness and ability to learn, the costs of retraining, and whether the training investment will be recouped because older workers have relatively less time remaining in the workforce compared to younger workers (Aaronson and Housinger 1999; Heywood et al.1999; Hirsch, MacPherson and Hardy 2000; Hutchens 1993). Other evidence suggests, however, that specific firms may obtain a greater return from older employees who are less likely to quit (Bennington and Tharenou 1996; Schrank and Waring 1989).

In sum, economic research has tended to paint a negative picture of an aging workforce. While much economic research presents itself as objective, it is evident that certain cultural values towards older people underpin much of the research. Despite critiques of this work, the dominant view remains that population aging represents an economic threat, 
and there are economically rational explanations, if not justifications, for treating older workers differently.

\section{Labour Market Research}

Research in this field provides evidence of the effects of ageism in employment, including forced early exit, barriers to re-entering employment, the uncertain impact of increasing flexibility in employment, and the implications of gender segmentation.

First, research on unemployment examines statistical trends in levels and duration of unemployment, categorized by age groups (Council on the Ageing 1992, 1999). While unemployment levels are greater among youth, average duration of unemployment is much greater among older workers: once unemployed, they tend to stay unemployed (Lyon and Glover 1998). It seems that only in conditions of labour shortage do employers look to older workers to fill jobs (Appelbaum and Gregory 1990; McCallum 1990; Taylor and Walker 1998), even though improvement in economic conditions does not necessarily result in more jobs for older workers (George 1997). Employers often prefer other groups of workers to fill new jobs because of negative attitudes towards older workers (Council on the Ageing 1992; Encel and Studencki 1995) and because their long periods of unemployment sends a negative “quality signal” to employers (Kenyon and Wooden 1994).

Second, research shows the declining labour force participation rate of older men (Taylor and Walker 1998) as a result of organizational restructuring and downsizing, as well as ageism (e.g., Laczko and Phillipson 1991; Lyon and Glover 1998). Discrimination at work may also predispose older workers to opt for early retirement (Snape and Redman, 2003) which, combined with structural changes in the number and type of jobs available (Agarwal and deGroote 1998; Feldman and Kim 2000; Ruhm 1990), leads to high levels of unemployment for older workers (Chan and Stevens 2001; Hirsch, MacPherson and Hardy 2000; Sum and Fogg 1990a, 1990b). 
A third focus of research concerns the decline of stable, full-time jobs and the rise in “flexible” forms of employment - more casual, part-time work or short-term employment contracts. On the one hand, flexible employment is seen as providing opportunities for older workers (Feldman and Kim 2000; Hirsch, MacPherson and Hardy 2000; Matthews 1990; Teiger 1994), allowing them to partially withdraw from the labour force in a gradual transition to retirement or partially re-enter the labour market after early exit (Doeringer 1990; Feldman and Kim 2000). On the other hand, older workers are often relegated to low paid, precarious jobs, interspersed with periods of unemployment and declining living conditions (Lyon and Glover 1998). In addition, flexible jobs may involve lower pay (Appelbaum and Gregory 1990; Doeringer and Terkla 1990) and status than previous jobs (Christensen 1990; Appelbaum and Gregory 1990). Older workers are also poorly served by the vocational training systems (Hirsch, MacPherson and Hardy 2000) that may be necessary if they are to retrain and take advantage of these jobs.

Finally, research indicates that age discrimination constitutes a significant barrier for older workers. It takes a variety of forms: differential treatment in dealing with government agencies and recruitment firms, access to vocational training, as well as in direct recruitment and selection by firms (Encel and Studencki 1995; Watson and Shael 1997; Council on the Ageing 1992). Within the organization, older workers experience less chance of promotion (Adams 2002), less access to training and development (Agarwal and deGroote 1998), and lower performance appraisal ratings (Saks and Waldman 1998; Snape and Redman 2003).

To conclude, labour market research provides data on the problems and experiences of older workers. Traditionally, however, it has focused on the experience of older white male employees in developed countries (McCallum 1992). More recent research has specifically focused on the experience of older women (Encel and Studencki 1997; Leanna and Feldman 1992; Patrickson and Hartmann 1996) and older people in different cultures (e.g., Lim 2003; 
McCallum 1992). It shows the diversity of the older worker category and demonstrating the impact of factors such as education, gender, health, socioeconomic status, family responsibilities, ethnicity, etc. on labour market outcomes (Katz Olson 1994; Saunders 1996).

\section{Gerontology}

Gerontology encompasses a diverse and diffuse set of disciplines including psychology, medicine, politics, economics, sociology, history, literature and cultural studies. However, in this illustrative literature review, gerontological research that focuses on the social aspects of ageing or 'social gerontology' (Jamieson and Victor 1997) has been categorized under other disciplinary headings. In this section we focus on gerontology that views ageing as an individual-level phenomenon. This emphasis reflects the dominance of psychology, medicine, health and welfare in gerontology, a dominance that has contributed to a 'biomedical’ view of ageing (Estes and Binney 1991; Latimer 1997; Minkler 1991; Phillipson 1998).

This body of research has focused on understanding the nature and operation of agerelated stereotypes, i.e., "widely held beliefs regarding the characteristics of people in various age categories” (Rosen and Jerdee 1976a: 180 and Rosen and Jerdee 1976b: 428), that become increasingly negative when attributed to older age categories (Aaronson 1966). Heavily influenced by psychology, such research adopts a conventional view of stereotypes (Pickering 2001) as perceptual 'shortcuts', inaccurate because they assume group homogeneity and stability. This perspective on stereotypes has led to a proliferation of empiricist research that has sought to prove or disprove the accuracy of such stereotypes, compared to an objective and measurable 'reality’ (Pickering 2001: 14), using experimental research designs and quantitative methodologies. Research within this field has yielded substantial evidence to challenge many of the negative assumptions and stereotypes about older workers (Bennington and Tharenou 1996; Chapman 1993; Johnson and Zimmerman 
1993; Laczko and Phillipson 1991; Levine 1988; Lim 2003; Warr 1994; White Riley and Riley Jr. 1989), such as them being less motivated, less able to learn, less physically able and are more resistant to change compared to younger workers (Cleveland and Landy 1983).

For example, while there is evidence of some decline in flexibility in problem-solving and cognitive processing speed, few generalizations can be made about differences in learning and memory between younger and older adults (Levine 1988). Some studies have argued that intelligence in older people is marked by both growth and decline (Cremer 1994; Staudinger, Cornelius and Baltes 1989). Tasks can have a positive age-effect if they involve knowledgebased judgements with no time pressure, or where expertise is useful (Warr 1994). Even where older adults are found to be slower in acquiring new skills compared to younger counterparts, this may be a function of training design (Stern and Doverspike 1989). This body of research suggests that the ageing process is contingent upon a range of social factors, including work design and quality of work, employment opportunities, attitudes to older workers and work environment (Agarwal and deGroote 1998; Avolio, Waldman and McDaniel 1990; Dixon 1970; Sheppard 1970).

Such negative stereotypes have been found to influence employment related decisions, such as recruitment, training and development, performance appraisal and redundancy (Avolio and Barrett 1987; Cleveland and Landy 1983; Ferris, Yates, Gilmore and Rowland 1985; Finkelstein, Burke and Raju 1995; Rosen and Jerdee 1976b). And despite the research evidence disproving their 'accuracy', negative stereotypes continue to influence both the actions and attitudes of employers, employees, and older people themselves (e.g., Barnes et al. 1999): researchers have argued that they are even internalized by members of the older population to become a self-fulfilling prophecy. For example, if older people feel they have less need or right to work than other groups, particularly in times of high unemployment, they may give up looking for work and become a discouraged job-seeker (Laczko and Phillipson 
1991). Negative stereotypes may lead to a loss of coping abilities, competence, and sense of control (Rodin 1989), as well as a deterioration in health (Butler 1989). In addition, stereotypes tend to identify the object of the stereotype as "problematic", which may lead them to incorporate definitions of themselves as problematic into their own identity (Schabracq 1994).

In sum, research in gerontology indicates that chronological age is a poor predictor of job performance and productivity, and factors other than age help to explain outcomes. While research in this field has provided data to debunk myths about older people, negative stereotypes continue to persist, and gerontology has had little effect in either challenging them or influencing programs that are better designed to address the needs of older workers.

\section{Cultural Studies}

The term "cultural studies" is used to denote research that focuses on aging as a cultural, social and collective - rather than an individual - phenomenon. Drawing on ideas of social constructionism, this work challenges the idea of a pre-existing self, separate from society and possessing inherent or essential characteristics. Instead, it sees identity - the meaning attached to the self - as arising out of social interaction and shared processes of meaning-making (see Gergen 1999; Hacking 2000). It acknowledges that "all knowledge, and therefore all meaningful reality as such, is contingent upon human practices, being constructed in and out of interaction between human beings and their world, and developed and transmitted within an essentially social context” (Crotty 1998: 42). In the context of the older worker, this is not to say there is no biological change with ageing, but that the meaning of these changes is culturally and socially constructed (Gullette 1997).

In this way, research in cultural studies accepts that aspects of identity, such as age, gender and ethnicity are socially constructed categories (Fulcher and Scott 1999). It shows how entry into older age is created and signified by language use (Gullette 1997). When an 
individual notices biological or physical change and attributes it to, or describes it as, agerelated decline, he or she is reproducing or sustaining the "master cultural narrative" of aging as inevitable decline. The culturally constructed nature of age categories is illustrated by the social phenomenon of the "mid-life" as a means of distancing from old age. However, this construction prematurely ages people as they are categorized as belonging to a group with a particular cultural meaning that signifies the start of inevitable age-related decline.

Age is also a body-based system of social categorization and, while it is not the only stage of the lifecycle that is socially and culturally constructed, it is the target of particular cultural ambivalence. This is evident in the tendency to deny the category altogether, and its element of self-hatred.

[T]here is not much serious discussion about eliminating infancy, adolescence or adulthood from the developmental landscape. It is only old age which comes under the scalpel. Why? (Andrews 1999: 302)

There are parallels between age and other body-based systems of social categorization, such as gender or ethnicity, but ageism is different in that hostility is directed against a future self, not a clearly differentiated "other” (Andrews, 1999). Accordingly, while many people may be able to maintain a perception of older people as totally separate from themselves, there comes a point at which people will identify with - and become part of - the category of older age.

Aging is thus an embodied process in that a gendered and bio-medicalized body is the site of aging (Tulle-Winton 1999). Western societies have a long history of cultural ambivalence towards the aged, often viewing aging as a form of bodily betrayal (Warren 1998). The aging body is seen a "cultural icon of decline and helplessness” (Tulle-Winton 1999: 297). A parallel development is the commodification of the physical body as promoted in popular culture, as well as the health, beauty and self-help industries. Although not exclusively concerned with aging, it involves a heavy emphasis on the denial of aging, 
combating aging, and "anti-aging”. "Successful” aging is problematic in that, to be culturally acceptable, older bodies must be managed. It may offer the possibility of rejecting the "aging as inevitable decline” cultural narrative (Gullette 1997), but it also reinforces the cultural repression of aging bodies by conforming to a youth-centred ideal that seeks to hide, mask or deny aging. It also individualizes the process of cultural aging, undermining the potential for collective resistance to ageism (Gullette 1997).

In sum, research in cultural studies focuses on the cultural construction of aging. Rather than taking the identity of older age for granted, it addresses the collective meaning and contingent nature of the identity of older people. It has not, however, addressed the processes whereby the category of older age is constructed. Nor has it dealt with the economic and material effects of being categorized as an older worker (du Gay 1996, 1997; Morris 1988), as the cultural construction of physical decline is associated with increasing economic insecurity, such as early retirement, unemployment or flexible employment (Gullette 1997).

To conclude this review of research on older workers, we can see that each of the fields has made a contribution to our understanding of older workers and yet they have some obvious limitations (Table 1). Economics has concentrated on the costs of population aging and income-related issues, but has neglected the social implications of aging, the diversity of the older population and constraints on individual behaviour. Despite these limitations it has been extremely influential in how aging is perceived by policy makers and the public. Labour market research has provided information on key issues relating to the position and experience of older people in the labour market, such as early exit from the workforce by older men and the prevalence of age discrimination and negative stereotypes in employment. Yet it does not explore why and how such age discrimination exists or how it is maintained. Many age-related myths have been debunked in gerontology; yet this research has had little impact dismantling stereotypes that continue to influence labour market behaviour. Cultural 
studies focuses on the social and cultural meanings of aging, and treats age as a culturally constructed phenomenon, contingent on context. Yet it does not account for the processes by which age identity is constructed or consider the material outcomes.

— Table 1 near here —

\section{Critical Discourse Analysis}

Many of the limitations of the literature reviewed above revolve around a tendency to take the concept of the "older worker” for granted. As such, most research fails to acknowledge that the concept of the older worker as an older white male in a career job, who proceeds from full-time work to full-time retirement somewhere in his early to mid-sixties, no longer dominates. This unitary identity was a product of a particular historical stage of industrial, modernist capitalism (du Gay 1996; Pateman 1989) that has since fragmented due to the increasing complexity of pathways from work to retirement, growing instability of employment, and greater workforce heterogeneity. In other words, the very notion of the “older worker” is problematic, ${ }^{3}$ and not even cultural studies provides a satisfactory way to explore how this identity comes into being in the first place, what alternative identities may be possible, or what their social and economic implications are. In order to address these more fundamental questions, we must turn to CDA. We use the term CDA in a broad sense to encompass the work undertaken in a number of different disciplines (see, for example, Fairclough 1992; Grant et al. 1998; Phillips and Hardy 2002; van Dijk 1997a). Simply put, CDA involves the use of discourse analytic techniques, combined with a critical perspective, to interrogate social phenomena. It builds on cultural studies insofar as it draws on social constructionist assumptions, but provides systematic techniques with which to implement them in the academic project, and also provides a critical framework with which to explore material effects (Wood and Kroger 2000; Powers 2001; Phillips and Hardy 2002; Phillips and Jorgensen 2002). ${ }^{4}$ 


\section{Discourse Analysis}

Discourse has been variously defined (e.g., Jaworski and Coupland 1999) as a “recognizable collection of statements which cohere together” (Wetherell 2001: 194), the “institutionalized use of language and language-like sign systems” (Davies and Harré 1990: 47), and a set of social practices that “make meaning” (Jaworski and Coupland 1999: 7). [Discourse is] a group of statements which provide a language for talking about a topic and a way of producing a particular kind of knowledge about a topic. Thus the term refers both to the production of knowledge through language and representations and the way that knowledge is institutionalized, shaping social practices and setting new practices into play. (du Gay 1996: 43)

Discourse is inaccessible in its entirety, but traces of it are found in the texts that help to constitute it (Burman and Parker 1993; I. Parker 1993). While discourses are realized through texts, they are much broader than texts and include the broader social and cultural structure and practices that surround and inform their production and consumption (Fairclough 1992; Phillips and Hardy 1997). Texts have an ideational function in that they constitute forms of knowledge and beliefs; an interpersonal function in that they help to construct certain forms of self or social identities; and a relational function in terms of how they contribute to social relations between different actors. These functions constitute discourse as a form of social practice and action (Fairclough 1995; Halliday 1994), whereby discursive practice can be defined as "all the ways in which people actively produce social and psychological realities" (Wetherell 2001: 193)

There are different approaches within discourse analysis: some focus on the microlevel of language use, whereas others discuss discourse as a much broader phenomenon as a way of communicating about a particular topic (Alvesson and Karreman 2000); some studies focus on the structure of text and talk, while others discuss discourse as a more abstract and 
philosophical topic (Ainsworth and Hardy in press); other distinctions can be drawn between studies that are descriptive and attend to local language use, and those that are critical and focus on the relationship between discourse and broader political contexts (Jaworski and Coupland 1999; Phillips and Hardy 2002; van Dijk 1997a). Despite differences that make it “difficult to speak of ‘discourse’ or even 'discourse analysis’ as a single unitary entity”, Burman and Parker (1993: 3) argue that discourse analytic approaches share a "common attention to the significance and structuring effects of language, and are associated with interpretive and reflexive styles of analysis.” Studying discourse therefore entails studying language use as a form of social practice (Candlin 1997; Fairclough 1992) that shapes society (Jaworski and Coupland 1999) by constructing versions of the social order.

Discourse plays an important role in the processes that go towards “making up” people as new categories of people are brought into being and "new ways for people to be" (Hacking 1986: 223). For example, the ascendance of statistics in the $19^{\text {th }}$ century was particularly influential in creating classifications for previously unknown types of people. These classifications then affected the "possibilities for personhood" for those targeted by, and enumerated according to, such categories. Discourse analysis thus involves an interest in the ways social members categorize themselves (van Dijk 1997a). It approaches identity as an ongoing process accomplished through social interaction (Antaki and Widdicombe 1998), particularly language and communication. Discourse does not transparently reflect the thoughts, attitudes and identities of separate selves but is a shared social resource that constructs identity as individuals lay claim to various recognizable social or shared identities. ${ }^{5}$ Central to this process is social categorization as various classifications of people are brought into being, with practical effects for those targeted by these categories, as well as those involved in their construction (Hacking 2000). Accordingly, the construction of identity in discourse is also the construction of meaning and relationships (Gergen 2001).While 
categories may seem natural and obvious, research has been particularly important in showing how they are a contingent, unstable product of particular historical circumstances (e.g., Hall 1997), achieved by differentiating and excluding that which is "other” (Laclau 1990). Such differentiation occurs within the context of particular discourses, not outside of them (Hall 1997). Discursive studies of identity thus challenge many of the assumptions of traditional psychological research by showing that individual identity is constructed from social resources (Potter and Wetherell 1987) and that, far from being unitary and pre-existent, the individual is a fragmented and ambiguous construction, dependent on context and relationships with others for its self-definition and meaning (Wetherell 2001).

\section{A Critical Framework}

The social constructionist assumptions that underpin discourse analysis do not reject the material existence of reality independent of human consciousness but assert that "reality" is only knowable through social processes of meaning-making (Crotty 1998: 9-10). It asserts that "truth" reflects the social and historical context, and processes of meaning-making of a given community. Such contingency has critical potential by showing that any particular version of reality is not natural or inevitable and, in fact, may serve political aims of specific interest groups (Mumby and Stohl 1991).

To the extent that my interests determine how it is I describe the world, then my descriptions lose the capacity to objectively describe.... More broadly, if you can detect my personal interests you throw my authority into disrepute (Gergen 1999: 21).

Such an approach is consistent with critical social science in its attempts to "de-familiarize" and “de-naturalize” taken for granted assumptions about social reality (Alvesson and Deetz 2000; Alvesson and Willmott 1992; Fournier and Grey 2000; Thompson forthcoming). 
Critical approaches to discourse analysis draw upon the work of Bourdieu, Derrida, Lyotard and, in particular, Foucault to emphasise the contextually contingent nature of truth claims, to show how they developed in relation to particular circumstances, and to explore alternatives to current arrangements and institutions (Alvesson and Deetz 2000; Grant et al. in press). Foucault was responsible for radically historicizing the notion of the subject by showing that the discursive formations that emerge in different historical periods produce specific kinds of identities (Hall 1997). For example, it was only with the intersection of discourses of sexuality with other medical, legal discourses and institutions of the late nineteenth century that produced the socially recognizable identity of the homosexual (Hacking 1986; Hall 1997). Discourse thus creates identities that individuals must take up to make sense of the discourse, and, in so doing, individuals subject themselves to its disciplinary effects (Howarth and Stvrakakis 2000). In other words, rather than autonomous subjects using discourse to construct identities, it is discourse that produces power-knowledge relations within which subjects are positioned, identities are constructed and bodies are disciplined (e.g., Trethewey 1999, 2001; du Gay 1996; Covaleski et al. 1998).

The Foucauldian perspective has been criticised for being overly fatalistic (Burman and Parker 1993; Hardy and Phillips in press). It fails to recognize that discourses are an expression of strategies of control by identifiable actors within a wider historical and institutional context (Fairclough 1992; Reed 1998). Accordingly, CDA tempers Foucault’s deterministic view of discourse by arguing that discourses are never completely cohesive, and are therefore never able to totally determine social reality. Actors are commonly embedded in multiple discourses, which provide a discursive space in which the actor can play one discourse against another or draw on multiple discourses (Fairclough 1992, 1995; Hardy and Phillips in press). Thus the limits and contradictions of discourse provide a substantial space for self-interested action (Keenoy et al. 1997: 150; Mumby and Stohl 1991). 
Discourse as a political practice establishes, sustains and changes power relations, and the collective entities (classes, blocs, communities, groups) between which power relations obtain. Discourse as an ideological practice constitutes, naturalizes, sustains and changes significations of the world from diverse positions in power relations. (Fairclough 1992: 67)

By examining "how communication practices construct identities, experiences and ways of knowing that serve some interests over others” (Mumby 2001: 614), CDA reveals the reproduction of power relationships and structures of inequality (Chouliaraki and Fairclough 1999; Fairclough 2001; Fairclough and Wodak 1997; van Dijk 1997b), and how the contradictory nature of the discursive field creates space for resistance (Weedon 1999).

CDA uses systematic and detailed forms of textual analysis drawn from conversation analysis, institutional dialogue, pragmatics, etc to examine texts. In the context of identity, texts are seen as "empirical materials that articulate complex arguments" about social identities of race, class, gender, sexual orientation, age etc. (Denzin 1994: 509). In addition, CDA combines these forms of analysis with the concept of intertextuality (Bakhtin 1981; Fairclough 1992, 1995; Kress and Threadgold 1988; Thibault 1991), reminding us that while texts may be the discursive units on which the researcher focuses, any individual text is "a link in a chain of texts, reacting to, drawing in and transforming other texts” (Fairclough and Wodak 1997: 262). In this way, CDA “mediates the connection between language and social context, and facilitates more satisfactory bridging of the gap between texts and contexts” (Fairclough 1995: 189). Consequently, it takes us beyond simple examinations of verbal and written interaction and allows us to appreciate the broader political context, as well as material implications (Grant et al. in press)

This approach has been used in a number of studies of identity that are collectively termed discourses of difference (Wodak 1996) or the discursive politics of representation 
(Hall 1997; Pickering 2001). Such research explores the discursive construction of identity of marginalized groups, especially gender and ethnic/racial identities. For example studies have explored how texts construct, reproduce and resist masculine and feminine identities (Alvesson 1998; Cameron 1997; Edley and Wetherell 1997; Mumby and Clair 1997; Nilan 1995; Stokoe 1998; Tannen 1994; West, Lazar and Kramarae 1997). Another focus has been the reproduction of racism and ethnic prejudices: discourses embody prejudices that, in turn, manifest themselves in racist views, practices, and behaviour. Discursive analyses of the media and news events have explored how the frames - rhetorical devices that define or assign interpretation to the social event - influence how people come to understand a topic (Mumby and Clair 1997; van Dijk 1991). Other research has looked at how racism is enacted and perpetuated in talk about minority groups (Bigler 1996; De Cilia, Reisigl and Wodak 1999; Kleiner 1998; van Dijk 1997c; van Dijk, Ting-Toomey, Smitherman and Troutman 1997; Wodak 1997; Wodak and Matouschek 1993).

Another interest concerns the effects of discourse: the social categories constructed in discourse have important implications for those involved. Using the illustration of the “woman refugee”, Hacking (2000) shows how the individual is affected by classification: if she is not thus classified, she may be deported, or go into hiding, or marry to gain citizenship.... She needs to become a woman refugee in order to stay in Canada; she learns what characteristics to establish, knows how to live her life. By living that life, she evolves, becomes a certain kind of person (a woman refugee). And so it may make sense to say that the very individuals and their experiences are constructed within the matrix surrounding the classification “woman refugees”... the individual herself is socially constructed as a certain kind of person (Hacking 2000: 11). 
Not only is individual experience affected through such classifications of identity: so too are social practices. Research by Hardy and colleagues (Hardy and Phillips 1997; Hardy, Phillips and Clegg 2001; Phillips and Hardy 1999) has examined how competing ideas of a refugee identity emerge from complex institutional fields. Different organizations have vested interests in different constructions of this identity. For example, governments require the identity of the "bogus" refugee to legitimate border control; nongovernmental organizations rely on the identity of the "genuine" refugees to justify their mandate of service provision. These organizations use a range of discursive resources to promote certain versions of refugee identity, which affect their own practices as they are applied to particular individuals.

The (unstable) concept of the refugee emerges out of this discursive struggle, changes in the meaning of which have material effects for those so labelled. Moreover, it is not only refugee identity that is produced in such discursive practices, but a range of other individual and organizational identities.

[I]n the case of refugee discourse, it is not just refugees that are produced; so, too, are the immigration officers who admit them; the decision-makers who determine their status; the members of NGOs who provide them with services; the media which report on them; the public who read about them. The organizations involved also construct their organizational 'subjectivities' or, as we refer to them here, their identities, through their discursive activities (Phillips and Hardy 1997: 169).

Like the concept of refugee, the older worker identity is a classification that involves an interaction between the classification and those classified, as well as the larger infrastructure of institutions, arrangements and practices surrounding the classification. CDA is interested in this institutional context and social practices connected to constructions of identity, as well as the implications such constructions have for those targeted by older worker identity. 
To summarize, according to CDA, discourse constructs identities by defining groups, their interests, their position within society, and their relationship to other groups (van Dijk 1997a). Language users engage in text and talk not just as individuals, but also as members of multiple social categories who construct identities through discourse (van Dijk 1997a). These identities are not fixed or stable but, rather, the outcome of a complex and contradictory interplay of discourses (Garsten and Grey 1997; Hardy, Lawrence and Grant, forthcoming) by actors with competing interests (Mumby and Clair 1997). Various groups try and manage discourse to their advantage (Hardy and Phillips 1999, in press; Mumby and Clair 1997). Thus discourse, power and identity are intimately connected.

\section{The Contributions of CDA to the Study of the Older Worker Identity}

In this section, we explore the contributions of CDA in relation to the older worker identity. We argue that it is useful in exploring not only the products of social construction, such as versions of identity, but also the processes of construction that give rise to them and the material effects that follow from them. In the case of the older worker identity, we are particularly interested not only in how this identity is constructed but also how the stereotypes associated with it arise and endure, and the prospects for resisting them. In so far as material effects are concerned, we are interested in how the cultural/social meaning of aging affects the employment experiences of those categorized as older workers, the organizational and societal practices that contribute to their categorization, and the way in which changes in those practices might produce different material outcomes for the older worker. In this section, we examine how CDA could be used to identify insights that can contribute to research and practice. In contrast, we also show that none of the other research disciplines reviewed in this paper deal so well with these more fundamental issues (see Table 2 for an overview) 


\section{Processes of Construction}

We are interested in understanding the processes of construction whereby the category of the older worker identity and the meanings attached to it come into being in the first place. Rather than understand it as inevitable and natural, we need to explore the social and historical circumstances that give rise to it, as well as the ways in which these meanings are held in place. As we have already shown, none of the other disciplines deals adequately with these processes although the work in cultural studies goes some way to understanding the constructed nature of identity, aging and other social categories (Table 2). CDA provides a way to explore these processes at both the macro level and the micro level. Studies focusing on the former show how an assembly of discourses is ordered and presented as an integrated frame, with meanings that are widely accepted and taken for granted, while more micro studies make a detailed study of language in a specific micro-context, and treat discourse as an emergent and locally constructed phenomenon (Alvesson and Karreman 2000).

First, by using CDA to examine macro processes we can reflect on the construction of the category itself and the embedded cultural assumptions that, for example, depict older workers as a potential or actual burden on society, or equate the older worker identity with a particular constellation of other identity “markers”, such as white males of a certain age employed (or unemployed) in developing countries. In relation to older worker identity, CDA could be used in several ways to explore processes of social construction (see Phillips and Hardy 2002). For example, work on discourses of difference provides frameworks that can be applied to this area. It explores the operation and reproduction of negative stereotypes - in this case those that relate to the older worker - in relation to other socially constructed categories such as gender and ethnicity. Studies might examine how language use by employees, employers, politicians and government officials, the media - consciously or unconsciously - contributes to dominant discourses (cf. Garnsey and Rees 1996). By 
exploring patterns of argumentation, storytelling, and genres with regard to older worker identity, researchers are in a position to show how this identity is constructed and imbued with meaning, not only in the choice of words or terminology but also through a variety of lexical manoeuvres.

Another approach might be the use of genealogical studies to examine the "conditions of possibility” for particular knowledge to be “drawn upon in the exercise of power” (Knights 1992: 530). This approach has been used to ascertain how different management discourses have arisen and shaped organizational practice, including labour process theory (Knights and Willmott 1989), TQM (Knights and McCabe 2002), HRM (Townley 1993), and strategy (Knights and Morgan 1991). This approach helps to explain how specific contexts create the conditions of possibility for a particular discursive construction of older worker identity, and the meanings associated with it.

CDA can also be used to understand the processes whereby fluid meanings become institutionalized and reified. One way to do so is to combine CDA with institutional theory (Meyer and Rowan 1977; DiMaggio and Powell 1991) to identify how the nature of discourse - the degree to which a discourse is broad, coherent, or contested - helps to produce the institutions of social life i.e., the self-regulating mechanisms that shape individual behaviour (Phillips, Hardy and Lawrence, forthcoming). Related to this is the question of "scaling up" (Hardy 2004) i.e., how do texts come to represent more widely shared symbol systems (Taylor and Van Every 2000), in which semiotic devices are rendered increasingly objective and meaning becomes progressively more abstracted and taken for granted (Cooren and Taylor, 1997)? Work on “textualization” (Taylor et al. 1996) and "recontextualization” (Iedema and Wodak 1999) shows how particular texts become distanced from the circumstances of their production and, in so doing, create enduring meanings (Harley and Hardy 2004). In the case of older worker identity, this might involve examining how stories, 
stereotypes and, in particular, statistics based on particular assumptions become reproduced, distributed and eventually reified into “facts” concerning older workers.

Second, by understanding processes of construction at the micro level, we are better placed to understand the way in which constructions of identity constrain individuals, as well as the prospects for resistance by marginalized groups like older workers. For example, a CDA study of older worker identity could examine how particular meanings attached to this identity influence the behaviour of individuals who are targeted by them. By focusing on the older workers' "lived experience” in a particular workplace and, especially, the way in which the day to day activities of their work are carried out, it is possible to track normalization processes and disciplinary techniques. In this way, researchers are able to explore how control is exercised through technologies - such as supposedly rational managerial programs - that constitute individuals as particular types of subjects (e.g., Covaleski et al. 1998; Townley 1993). Equally, research can trace how local texts, narratives, and myths act as forms of social control through the way in which they author identities (e.g., Langellier and Peterson 1993; Witten 1993). While researchers have examined diverse forms of social control through discourse, there are few such studies of the older worker identity, although Trethewey (2001) has shown how middle-aged women in organizations are made individually responsible for managing their aged selves through strategies of consumption and self-presentation at work.

By understanding the complex relationship between control and identity, we can also start to explore resistance. How can workers escape the practices and techniques that discipline them at work by virtue of being constructed as “older”? If language use, narratives and myths help to construct the older worker, can countervailing language, narratives and myths be used against them? If texts make up the discourses that constrain them, can older workers produce their own texts to shape the meanings that disadvantage them? Within the context of the discourses related to older workers, what subject positions exist that warrant 
voice (Potter and Wetherell 1987) and that can be appropriated by older workers? What other discourses can be drawn upon to accord the older worker a degree of agency? Can texts that support the dominant discourse be subverted and undermined (cf. De Certeau 1984; Ezzamel et al. 2001; Murphy 1998)? In other words, can localized forms of resistance "lead to the systematic undermining of the dominant hegemony” (Mumby 1997: 17) associated with older worker identity?

\section{Material Effects}

We are interested in accounting for the material effects of constructions of the older worker identity in two senses: their implications for organisational-level employment practices and the broader socio-cultural position of older workers. While the material effects of age discrimination in the labour market have been addressed by economics and labour market research, this has not been connected to the construction of age identity (see Table 2). Cultural studies has explored the culturally constructed meaning of aging, and offered different ways of conceptualizing aging but has tended to neglect the economic sphere, including age and employment. CDA is not only interested in how discourse works but also in what it does i.e., its material effects and implications (Deetz 1992). In the case of older worker identity, this would involve research that explored the connections between certain versions of identity, the processes of their construction, and their relationship with organizational practices, such as recruitment, redundancy programs, training and development, as well as broader social implications, including trends in unemployment, labour force participation and income levels.

First, at the organisational level, CDA research in other settings has shown that the way in which identities are constructed has implications for how particular organizational practices are enacted (e.g., Phillips and Hardy 1997). In this way, CDA provides detailed empirical illustrations of the mutually constitutive relationship between discourse and context 
i.e., how specific contexts create the conditions of possibility for a particular discursive construction of older worker identity and how, in turn, these constructions influence context, leading to certain actions and outcomes. In the case of the older worker, organizational members are influenced by broader discourses that encompass enduring stereotypes that tend to construct the older worker as less effective, efficient, mentally agile than other workers: they represent a poor investment for business. CDA might therefore relate the impact of such taken for granted meanings on specific employment practices. For example, how does the way in which managers think about older workers produce recruitment practices that screen them out (and how are such decisions discursively constructed to distance such decisions from age discrimination cf. Mauws 2000)? How do training programs operate as technologies of control and what are the implications for those older workers excluded from then; or how do older workers who do gain access engage in them? How are redundancy programs developed; what implicit assumptions underpin them; and what are the consequences for individual older workers? Do practices vary among organizations that construct the older worker in different ways?

Second, at a broader societal level, policies and legislation are developed as a result of particular understandings of the older worker. One outcome that we have already discussed has been to understand the older worker as a potential "burden". Political debates - and the resulting legislation - have tended to focus on ways of "reducing” this burden. CDA offers the capacity to unmask this cultural bias and to show how it infiltrates research on older workers especially in economics and labour market studies, as well as the subsequent followon effect on macro-level public policy. At a more nuanced level, we know that general conceptions of the older worker tend to see this identity as predominantly male, blue collar, and recently retrenched. Research has shown how the older female worker, who faces very different employment hurdles as a result of discontinuous work histories and care-giving roles 
is written out of the discourse (Ainsworth 2002). The consumption and delivery of services, such as health and age care, are influenced by the construction of age identities (cf. Coupland, Coupland and Giles 1991; Coupland and Nussbaum 1993; Stephenson et al., 1999; YalnneMcEwen 2000). As a result, policy initiatives are likely to lead to recommendations geared towards males in particular circumstances and which ignore the needs of older females. In other words, legislation is not only based on a particular definition of the "problem", but its definition misses a large part of that "problem"; no wonder then that policies fail.

By using CDA, researchers can explore how aging and older workers are represented in public policy debates, academic research and the media, and the implications this has for employment. The nature of this research approach does not rest on establishing a cause and effect relationship between discourse and material outcomes, but it nonetheless can provide persuasive accounts that show how, by constructing older workers in certain ways, they are made amenable to a specific range of actions. Moreover the processes of discursive construction influence and constrain the versions of identity constructed, which in turn affect social practices; as actors draw on broader societal discourses in constructing identities, these broader discourses make possible a limited range of "sensible" constructions which, in turn, provide for a limited range of "sensible” behaviour and social practices.

\section{Conclusions}

By systematically reviewing and assessing the contribution of different research disciplines to our understanding of older workers, we have been able to establish some key gaps that CDA helps to address. Economic research has been dominated by a concern with the costs of an aging population and has been extremely influential in public policy and public opinion. Yet this research is often based on an implicit ageism. Labour market research has examined the affects of age discrimination in employment, and tracked patterns in labour force participation, but cannot explain how and why such age discrimination persists. 
Gerontology has made important contributions by debunking many of the ageist stereotypes about older workers, yet it has had surprisingly limited influence on government and organizational practice. Cultural studies has examined the contingency of age identity and the collective values underpinning certain constructions, but has not focused on the processes of construction, nor on their employment-related affects.

We advocate CDA because of its combined critical and constructionist approach. We also acknowledge that there are limitations to this approach. In unpacking and challenging dominant discourses and taken for granted meanings, CDA critiques and problematizes powerful authorities but, in keeping with social constructionism, any basis of authority, including those favoured by critical inquiry must be open to interrogation. From the perspective of social constructionism, all truth claims are constructions.

For constructionists, all claims to "the real" are traced to processes of relationship, and there is no extra-cultural means of ultimately privileging one construction of reality over another (Gergen 2001: 8).

This is the basis for charges of moral or political relativism directed at social constructionists by critical theorists, who assert that it leaves no basis for adjudicating between different truth claims (Parker 1992; Thompson 1993; Thompson forthcoming; Tsoukas 1992). These researchers have also argued that social construction does not direct attention to material conditions and institutions that structure the very possibility of generating alternative accounts of social reality (Thompson forthcoming; Tsoukas 1992). However, we would argue that CDA circumvents some of these problems by questioning the validity of the dualism between material conditions and discourse and can be used to show how material conditions and practices are embedded within the scope of discourse (Fournier and Grey 2000).

A second limitation stems from the contradiction of assuming that social constructionism itself can be accorded foundational status: 
While constructionist critiques may often appear nihilistic, there are no means by which they themselves can be grounded or legitimated. They too fall victim to their own modes of critique; their accounts are inevitably freighted with ethical and ideological implications, forged within the conventions of writing, designed for rhetorical advantage, and their "objects of criticism” constructed within and for a particular community. The objects of their criticism are no less constructed than the traditional objects of research, nor do their moral claims rest on transcendental foundation. (Gergen 2001: 30).

This limitation reminds researchers to attend to calls for greater reflexivity: "interpreting one’s own interpretations, looking at one’s own perspectives from other perspectives, and turning a self-critical eye onto one’s own authority as interpreter and author” (Alvesson and Skoldberg 2000: vii). Reflexivity directs attention to the contingency of categories of research, and the incompleteness and partiality of its explanations and assumptions (Antonocoplou and Tsoukas 2002). It involves more provisional reality claims, a recognition of the contingency of accounts of reality, a skepticism towards foundational claims to truth, and a plurality of views (Alvesson and Deetz 2000; Grant et al. 2004).

We would also argue that, in keeping with the reflexive use of CDA, such research should acknowledge that, in order to understand and address social problems - the emancipatory component of CDA - other fields of study have a contribution to make. In many respects, CDA needs these other theories: by the nature of its epistemological assumptions, CDA cannot establish, for example, whether negative stereotypes of older workers are accurate; nor can it be used to identify trends in unemployment, or disparities income levels. What CDA can do is challenge, critique and interrogate the studies and findings of other theoretical approaches, particularly those informed by positivist assumptions. In many regards, by paying attention to a particular phenomenon and drawing 
particular conclusions about it, other theories provide a target with which CDA can engage. It is, in fact, in the interests of CDA to engage with these other theories, at the same time as it is not in the interests of these other theories to engage with a form of analysis that is intent upon undermining them. Thus does discursive struggle pervade the academic arena!

In the case of older workers, our criticism is that CDA has been slow to engage, despite large bodies of more traditional research that might represent a useful target. We are told that the population is aging, that older workers face disadvantages at work; we also know that other age related categories are causing "problems", such as aged care, health care and even the voting intentions of supposed "grey power". So far, although CDA has the potential to contribute to current understanding of older workers, age identity and employment have not received significant attention. Given that government agencies and organizations are actively developing policies to deal with the "problem" of an aging workforce, informed by numerous, usually unstated, assumptions about who the older worker is, in terms of psychological makeup, skills, work history, appearance, aspirations, gender and capacity to change, it would seem an opportune moment for CDA to engage.

We have tried to interrogate the contribution of CDA by contrasting it with other theories and examining what it can and cannot do. The amount of research on discourse has been growing considerably in recent years and in our own field, organization studies, it is difficult to open a journal without finding some sort of discursive based study (Grant et al. 2004). While we applaud the growing interest in this methodology, we believe it is important to ascertain exactly what CDA, and discourse analytic approaches more generally, contribute to the study of such phenomena. We do not believe, however, that these approaches should be used for their own sake, or that researchers should suspend their critical faculties when it comes to their own research methodology. Continuing to re-examine CDA is a component of the reflexive project of which CDA is a part. 
Table 1: Characteristics of Different Research Approaches to the Study of the Older Worker

\begin{tabular}{|c|c|c|c|c|}
\hline \multicolumn{5}{|c|}{ Table 1: Characteristics of Different Research Approaches to the Study of the Older Worker } \\
\hline Discipline & Key Concerns/Rationale & Basic Assumptions & Typical Methodology & Relevance \& impact \\
\hline Economics & $\begin{array}{l}\text { Demographic forecasting of } \\
\text { economic costs of supporting } \\
\text { an aging population } \\
\text { Productivity implications of an } \\
\text { aging workforce } \\
\text { Income \& pension effects on } \\
\text { retirement decisions } \\
\text { Economic models to explain } \\
\text { labour market behaviour (e.g., } \\
\text { of employers) }\end{array}$ & $\begin{array}{l}\text { Older people are part of the economically dependent } \\
\text { (non-productive) population } \\
\text { Economic consequences can be identified through } \\
\text { economic ratios/population forecasting } \\
\text { An aging workforce has economic and productivity } \\
\text { consequences } \\
\text { Economic consequences are a cause for concern } \\
\text { People make choices about retirement based on an } \\
\text { assessment of the economic benefits of different } \\
\text { alternatives } \\
\text { Labour market behaviour of employers vis-à-vis } \\
\text { older people is rational and can be explained by } \\
\text { economic factors }\end{array}$ & $\begin{array}{l}\text { Quantitative methodology } \\
\text { using various techniques: } \\
\text { Economic models and } \\
\text { ratios; forecasts from } \\
\text { demographic/population } \\
\text { data and trends; labour } \\
\text { force statistics and } \\
\text { industry data on } \\
\text { productivity }\end{array}$ & $\begin{array}{l}\text { Oriented towards policy, } \\
\text { influential on state policy } \\
\text { Key policy focus is funding the } \\
\text { costs of aging (social security, } \\
\text { health care, pensions) \& efficient } \\
\text { allocation of resources } \\
\text { Used to structure systems of } \\
\text { incentives/disincentives to older } \\
\text { people remaining in, or exiting } \\
\text { from, the workforce, e.g., } \\
\text { incomes, employment and social } \\
\text { security policy }\end{array}$ \\
\hline $\begin{array}{l}\text { Labour } \\
\text { Market } \\
\text { Research }\end{array}$ & $\begin{array}{l}\text { Labour market disadvantage } \\
\text { of older people } \\
\text { Barriers to market re-entry } \\
\text { Quantity and quality of jobs } \\
\text { Unemployment } \\
\text { Structural change in labour } \\
\text { market } \\
\text { Employment prospects } \\
\text { Research gaps: heterogeneity } \\
\text { of older age group }\end{array}$ & $\begin{array}{l}\text { Older workers are a disadvantaged group in need of } \\
\text { assistance and attention } \\
\text { Matching of supply and demand may result in } \\
\text { increased jobs for older people } \\
\text { Quantity of employment opportunities of more } \\
\text { importance than quality of jobs } \\
\text { The experience of older women in the labour market } \\
\text { is different from that of older men } \\
\text { The rise in flexible employment is a global trend - } \\
\text { an inevitable response to universal economic } \\
\text { pressures - with differential effects for older workers }\end{array}$ & $\begin{array}{l}\text { Quantitative: labour } \\
\text { market trends, } \\
\text { unemployment } \\
\text { Qualitative: case studies } \\
\text { to illustrate diversity of } \\
\text { older age group and } \\
\text { dynamics and connections } \\
\text { between education, career } \\
\text { history, unemployment, } \\
\text { etc. }\end{array}$ & $\begin{array}{l}\text { Oriented towards policy e.g., } \\
\text { labour market programs to assist } \\
\text { unemployed to gain jobs; job } \\
\text { creation programs; changing } \\
\text { rules governing access to social } \\
\text { security for over-45s } \\
\text { (unemployed) }\end{array}$ \\
\hline Gerontology & $\begin{array}{l}\text { Interrogating age stereotypes } \\
\text { Relationships between age \& } \\
\text { work performance or } \\
\text { productivity } \\
\text { Contingent nature of aging }\end{array}$ & $\begin{array}{l}\text { Stereotypes can be disproved by research } \\
\text { The aging process is experienced by individuals (the } \\
\text { individual is the unit of analysis) } \\
\text { Aging is affected by social conditions } \\
\text { Aging can (and should be) retarded where possible }\end{array}$ & $\begin{array}{l}\text { Quantitative: } \\
\text { psychological tests of } \\
\text { cognitive ability } \\
\text { (laboratory); work tests } \\
\text { Some qualitative: work } \\
\text { observation }\end{array}$ & $\begin{array}{l}\text { Oriented towards policy/practice } \\
\text { e.g., health and social services } \\
\text { policy; education and training } \\
\text { design; retraining although } \\
\text { relatively little impact compared } \\
\text { to economics research }\end{array}$ \\
\hline $\begin{array}{l}\text { Cultural } \\
\text { Studies }\end{array}$ & $\begin{array}{l}\text { Debate over how aging should } \\
\text { be conceptualized } \\
\text { Ageism and age ideology } \\
\text { The culturally constructed } \\
\text { nature of aging } \\
\text { Aging as an embodied (and } \\
\text { gendered) process }\end{array}$ & $\begin{array}{l}\text { Cultural values and norms, ideas and beliefs about } \\
\text { aging have a profound affect on the social status of } \\
\text { older people and the experience of aging } \\
\text { Aging is not an objective phenomenon - its cultural } \\
\text { meaning is socially constructed }\end{array}$ & $\begin{array}{l}\text { Qualitative: interpretive; } \\
\text { interactionist; auto- } \\
\text { ethnography } \\
\text { Theoretical }\end{array}$ & $\begin{array}{l}\text { Little policy/practice orientation } \\
\text { but potentially profound } \\
\text { influence in changing broader } \\
\text { social attitudes to aging and } \\
\text { identifying ways to resist }\end{array}$ \\
\hline
\end{tabular}




\begin{tabular}{|c|c|c|c|c|}
\hline \multicolumn{5}{|c|}{ Table 2: Contributions of Critical Discourse Analysis Compared to other Research Approaches } \\
\hline Discipline & \multicolumn{2}{|c|}{ Processes of Construction } & \multicolumn{2}{|c|}{ Material Effects of Identity } \\
\hline & $\begin{array}{l}\text { Conceptualizes processes of } \\
\text { construction of the older worker } \\
\text { identity at the level of "macro" } \\
\text { discourse }\end{array}$ & $\begin{array}{l}\text { Conceptualizes process of } \\
\text { construction of the older worker } \\
\text { identity at the level of "micro" } \\
\text { discourse }\end{array}$ & $\begin{array}{l}\text { Accounts for the marginal } \\
\text { employment position of older } \\
\text { workers }\end{array}$ & $\begin{array}{l}\text { Accounts for the marginal socio- } \\
\text { cultural position of older workers }\end{array}$ \\
\hline $\begin{array}{l}\text { Critical } \\
\text { Discourse } \\
\text { Analysis }\end{array}$ & $\begin{array}{l}\text { Provides well-established } \\
\text { framework to show how discourses } \\
\text { acquire dominant and taken for } \\
\text { granted meanings }\end{array}$ & $\begin{array}{l}\text { Provides a well-established } \\
\text { framework to show how local } \\
\text { struggles around discourse can } \\
\text { change meanings }\end{array}$ & $\begin{array}{l}\text { Existing work limited but studies } \\
\text { of other identities indicate its } \\
\text { potential as an analytical } \\
\text { framework }\end{array}$ & $\begin{array}{l}\text { Existing work limited but studies of } \\
\text { other identities indicate its potential } \\
\text { as an analytical framework }\end{array}$ \\
\hline Economics & No & No & $\begin{array}{l}\text { Job rationing model relevant but } \\
\text { provides an insufficient } \\
\text { explanation. }\end{array}$ & $\begin{array}{l}\text { Does not recognize the construction } \\
\text { of identity but can be seen as } \\
\text { focusing on its economic effects, } \\
\text { e.g., income, costs of aging }\end{array}$ \\
\hline $\begin{array}{l}\text { Labour } \\
\text { Market } \\
\text { Research }\end{array}$ & No & No & $\begin{array}{l}\text { Provides data on trends \& } \\
\text { qualitative research illustrates } \\
\text { marginality of older workers }\end{array}$ & $\begin{array}{l}\text { Focus on outcomes e.g. } \\
\text { unemployment, age discrimination, } \\
\text { labour market barriers }\end{array}$ \\
\hline Gerontology & $\begin{array}{l}\text { No - research exposes lack of } \\
\text { accuracy of stereotypes (but not } \\
\text { why and how they are reproduced) }\end{array}$ & No & No & No \\
\hline $\begin{array}{l}\text { Cultural } \\
\text { Studies }\end{array}$ & $\begin{array}{l}\text { Explores identity as a culturally } \\
\text { constructed product, but not } \\
\text { processes of construction }\end{array}$ & $\begin{array}{l}\text { No - explores cultural meaning of } \\
\text { older age (but not age and } \\
\text { employment). Explores the content } \\
\text { of ageism and negative stereotypes } \\
\text { but not the processes by which } \\
\text { they are produced/sustained }\end{array}$ & $\begin{array}{l}\text { Some age theory does address the } \\
\text { marginal socio-cultural position of } \\
\text { older people, but little work links } \\
\text { this to employment }\end{array}$ & $\begin{array}{l}\text { Some age theory does address the } \\
\text { marginal socio-cultural position of } \\
\text { older people but does not } \\
\text { systematically link this to } \\
\text { constructions of age identity }\end{array}$ \\
\hline
\end{tabular}




\section{Bibliography}

Aaronson, B. S. (1966). Personality stereotypes of ageing. Journal of Gerontology, 21: 458-462.

Aaronson, D., \& Housinger, K. (1999). The impact of technology on displacement and reemployment. Economic Perspectives, 23, (2): 14-26.

Adams, S. J. (2002). Passed over for promotion because of age: An empirical analysis of the consequences. Journal of Labor Research, 23, (3): 447-62.

Agarwal, N. C., \& DeGroote, M. G. (1998). Retirement of older workers: Issues and policies. Human Resource Planning, 23, (1): 14-25.

Ainsworth, S. (2002). The "feminine advantage": A discursive analysis of the invisibility of older women workers. Gender, Work and Organization, 9, (5): 579-601.

Ainsworth, S. (2003). The discursive construction of older worker identity. Unpublished Ph.D. thesis, The University of Melbourne.

Ainsworth, S., \& Hardy, C. (in press). Discourse and identities. In D. Grant, C. Hardy, C. Oswick \& L. Putnam (Eds.). Handbook of organizational discourse. London: Sage.

Alvesson, M. (1998). Gender relations and identity at work: A case study of masculinities and femininities in an advertising agency. Human Relations, 51, (8): 969-1005.

Alvesson, M., \& Deetz, S. (2000). Doing critical management research. London, Thousand Oaks, New Delhi: Sage.

Alvesson, M., \& Karreman, D. (2000). Varieties of discourse analysis: On the study of organizations through discourse analysis. Human Relations, 53, (9): 1125-50.

Alvesson, M., \& Skoldberg, K. (2000). Reflexive methodology: New vistas for qualitative research. London, Thousand Oaks, New Delhi: Sage.

Alvesson, M., \& Willmott, H. (1992). Critical theory and management studies: An introduction. In M. Alvesson \& H. Willmott (Eds.). Critical management studies. London, Newbury Park: Sage. PAGES $1-20$.

Andrews, M. (1999). The seductiveness of agelessness. Ageing and Society, 19 (3): 301-18.

Antaki, C., \& Widdicombe, S. (1998). Identity as an achievement and as a tool. In C. Antaki \& S. Widdicombe (Eds.). Identities in talk. London and Thousand Oaks: Sage. PAGES 1-14.

Antonacopoulou, E., \& Tsoukas, H. (2002). Time and reflexivity in organization studies: An introduction. Organization Studies, 23, (6): 857-62.

Appelbaum, E., \& Gregory J. (1990). Flexible employment: Union perspectives. In P. Doeringer (Ed.). Bridges to retirement: Older workers in a changing labor market. Ithaca NY: ILR Press, Cornell University. PAGES 130-145. 
Avolio, B. J., Waldman, D. A., \& McDaniel, M. A. (1990). Age and work performance in nonmanagerial jobs: The effects of experience and occupational type. Academy of Management Journal, 33, (2): 407-22.

Avolio, B. J. and Barrett, G. V. (1987). Effects of age stereotyping in a simulated interview. Psychology and Aging, 2, (1): 56-63.

Baker, M. (2002). The retirement behavior of married couples. Journal of Human Resources, 37, (1): $1-34$.

Baker, M., \& Benjamin, D. (1999). Early retirement provisions and the labor force behavior of older men: Evidence from Canada. Journal of Labor Economics, 17, (4): 724-744.

Bakhtin, M. M. (1981). The dialogic imagination: Four essays by M. M. Bakhtin. C. Emerson \& M. Holquist (Eds.). Austin: University of Texas Press.

Barnes, P., Johnson, R., Kulys, A., \& Hook, S. (1999). Productivity and the structure of employment. Productivity Commission Staff Research Paper. Canberra: AusInfo.

Bennington, L., \& Tharenou, P. (1996). Older workers: Myths, evidence and implications for Australian managers. Asia Pacific Journal of Human Resources, 34, (3): 63-76.

Bigler, E. (1996). Telling stories: On ethnicity, exclusion and education in upstate New York. Anthropology and Education Quarterly, 27, (2): 186-203.

Blondal, S., \& Scarpetta, S. (1998). Retire early, stay at work? OECD Observer, 212: 15-20.

Brown, M. H. (1985). That reminds me of a story: Speech action in organizational socialization. Western Journal of Speech Communication, 49: 27-42.

Burman, E., \& Parker, I. (1993). Against discursive imperialism, empiricism and constructionism: Thirty-two problems with discourse analysis. In E. Burman \& I. Parker (Eds.). Discourse analytic research: Repertoires and readings of texts in action. London and New York: Routledge. PAGES 155-172.

Butler, R. N. (1989). Dispelling ageism: the cross-cutting intervention. In M. White Riley and J. W. Riley Jnr. (Eds.). The Annals of the American Academy of Political and Social Science, The Quality of Aging: Strategies for Interventions, 503: 138-47.

Bytheway, B. (1995). Ageism. Buckingham, Philadelphia: Open University Press.

Cameron, D. (1997). Performing gender identity: Young men's talk and the construction of heterosexual masculinity. In S. Johnson \& U. H. Meinhof (Eds.). Language and masculinity. Oxford: Blackwell. PAGES 47-64.

Candlin, C. N. (1997). General editor's preface. In B. Gunnarsson, P. Linell \& B. Nordberg (Eds.). The construction of professional discourse. London: Longman. PAGES ix-xiv. 
Chan, S., \& Stevens, A. H. (2001). Job loss and employment patterns of older workers. Journal of Labor Economics, 19, (2): 484-521.

Chapman, P. G. (1993). Discussion. In P. Johnson \& K. F. Zimmerman (Eds.). Labour markets in an ageing Europe. Cambridge: Cambridge University Press. PAGES 146-150.

Christensen, K. (1990). Bridges over troubled water: How older workers view the labor market. In P. Doeringer (Ed.). Bridges to retirement: Older workers in a changing labor market. Ithaca NY: ILR Press, Cornell University. PAGES 175-208.

Choi, N. G. (2000). Potential consequences of raising the social security eligibility age on low-income older workers. Journal of Aging \& Social Policy, 11, (4): 15-39.

Chouliaraki, L., \& Fairclough, N. (1999). Discourse in late modernity: Rethinking critical discourse analysis. Edinburgh: Edinburgh University Press.

Clark, P. G. (1993). Public policy in the United States and Canada: Individualism, familial obligation, and collective responsibility in the care of the elderly. In J. Hendricks \& C. J. Rosenthal (Eds.). The remainder of their days: Domestic policy and older families in the United States and Canada. New York and London: Garland Publishing. PAGES 13-48.

Cleveland, J. N. and Landy, F. J. (1983). The effects of person and job stereotypes on two personnel decision. Journal of Applied Psychology, 68, (4): 609-619.

Cooren, F., \& Taylor, J. R. (1997). Organization as an effect of mediation: Redefining the link between organization and communication. Communication Theory, 7, (3): 219-59.

Correll, D. (1999). Valuing older Australians. Family Matters, Autumn: 31-35.

Council on the Ageing. (1992). What now? Over 45 and unemployed: Present realities and future trends for the older unemployed. Melbourne: Council on the Ageing.

Council on the Ageing. (1999). Older Australians: Working for the future. Strategic ageing: Australian issues in ageing, 9, (19): 10-18.

Coupland, N., Coupland, J., \& Giles, H. (1991). Language, society and the elderly: Discourse, identity and ageing. Oxford, U.K. and Cambridge, U.S.A.: Blackwell.

Coupland, N., \& Nussbaum, J. F. (Eds.) (1993). Discourse and lifespan identity. Newbury Park, CA: Sage.

Covaleski, M. A., Dirsmith, M. W., Heian, J. B., \& Samuel, S. (1998). The calculated and the avowed: Techniques of discipline and struggles over identity in big six public accounting firms. Administrative Science Quarterly, 43, (2): 293-327.

Cremer, R. (1994). Matching vocational training programmes to age-related mental change - a social policy objective. In J. Snel \& R. Cremer (Eds.). Work and aging: A European perspective. London: Taylor and Francis. PAGES 273-282.

Crotty, M. (1998). The foundations of social research: Meaning and perspective in the 
research process. Sydney: Allen and Unwin.

Crouch, A., \& Basch J. (1997). The structure of strategic thinking: A lexical content analysis. Journal of Applied Management Studies, 6, (1): 13-38.

Dahl, S. A., Nilsen, O. A., \& Vaage, K. (2000). Work or retirement? Exit routes for Norwegian elderly. Applied Economics, 32, (14): 1865-1876.

Davies, B., \& Harre, R. (1990). Positioning: The discursive production of selves. Journal of the Theory of Social Behaviour, 20: 43-65.

De Certeau, M. (1984). The practice of everyday life. London: University of California Press.

De Cilia, R., Reisigl, M., \& Wodak, R. (1999). The discursive construction of national identities. Discourse \& Society, 10, (2): 149-173.

Deetz, S. (1992). Disciplinary power in the modern corporation. In M. Alvesson \& H. Willmott, H. (Eds.). Critical management studies. London, Newbury Park, New Delhi: Sage. PAGES 21-45.

Denzin, N. (1994). The art and politics of interpretation. In N. K. Denzin \& Y. S. Lincoln (Eds.). The handbook of qualitative research. Thousand Oaks: Sage. PAGES 500-515.

DiMaggio, P. J., \& Powell. W. W. (1991). Introduction. In W. W. Powell \& P. DiMaggio (Eds.). The new institutionalism in organizational analysis. Chicago: University of Chicago Press. PAGES 267-292.

Dixon, D. (1970). Some economic aspects of gerontology. In H. L. Sheppard (Ed.). Toward an industrial gerontology: An introduction to a new field of applied research and service. Cambridge MA: Schenkman Publishing Company. PAGES 31-38.

Doeringer, P. B. (1990). Economic security, labor market flexibility, and bridges to retirement. In P. Doeringer (Ed.). Bridges to retirement: Older workers in a changing labor market. Ithaca NY: ILR Press. PAGES 3-22.

Doeringer, P. B., \& Terkla, D. G. (1990). Business necessity, bridge jobs, and the nonbureaucratic firm. In P. Doeringer (Ed.). Bridges to retirement: Older workers in a changing labor market. Ithaca NY: ILR Press. PAGES 146-174.

Donnellon, A. (1994). Team work: Linguistic models of negotiating differences. In R. J. Lewicki, B. H. Sheppard, \& R. Bies (Eds.). Negotiations in organizations, Volume 4. Greenwich, CT: JAI Press. PAGES 71-123.

Du Gay, P. (1996). Consumption and identity at work. London: Sage.

Du Gay, P. (1997a). Introduction. In P. du Gay (Ed.). Production of culture/Cultures of production. London: Sage. PAGES 1-10.

Du Gay, P. (1997b). Organizing identity: Making up people at work. In P. du Gay (Ed.). Production of culture/Cultures of production. London: Sage. PAGES 285-344. 
Edley, N., \& Wetherell, M. (1997). Jockeying for position: The construction of masculine identities. Discourse \& Society,8, (2): 203-217.

Encel, S. (2003). Age can work: The case for older Australians staying in the workforce. A Report to the Australian Council for Trade Unions and the Business Council of Australia, April.

Encel, S., \& Studencki, H. (1995). Job search experiences of older workers. Sydney: NSW Consultative Committee on Ageing.

Encel, S., \& Studencki, H. (1997). Gendered ageism: Job search experiences of older women. Sydney: NSW Committee on Ageing and the Department for Women.

Estes, C. L. and Binney, E. A. (1991). The biomedicalization of aging: dangers and dilemmas. In M. Minkler and C. L. Estes (Eds.). Critical Perspectives on Aging: The Political and Moral Economy of Growing Old. Amityville, NY: Baywood. PAGES 117-134.

Ezzamel, M., Willmott, H., \& Worthington, F. (2001). Power, control and resistance in the factory that time forgot. Journal of Management Studies, 38, (8): 1053-1079.

Fairclough, N. (1992). Discourse and social change. Cambridge: Polity Press.

Fairclough, N. (1995). Critical discourse analysis: The critical study of language. London: Addison Wesley Longman.

Fairclough, N. (2001). The discourse of New Labour: Critical discourse analysis. In M. Wetherell, S. Taylor \& S. J. Yates (Eds.). Discourse as data: A guide for analysis. London, Thousand Oaks, New Delhi: Sage in association with The Open University. PAGES 229-266.

Fairclough, N., \& Wodak, R. (1997). Critical discourse analysis. In T. A. van Dijk (Ed.). Discourse as social interaction, Discourse studies: A multidisciplinary introduction, Volume 2. London: Sage. PAGES 258-284.

Feldman, D. C., \& Kim, S. (2000). Bridge employment during retirement: A field study of individual and organizational experiences with post-retirement employment. Human Resource Planning, 23, (1): $14-25$.

Ferris, G. R., Yates, V. L., Gilmore, D. C. and Rowland, K. M. (1985). The influence of subordinate age on performance ratings and causal attributions. Personnel Psychology, 38: 545-557.

Finkelstein, L. M., Burke, M. J. and raju, N. S. (1995). Age discrimination in simulated employment contexts: an integrative analysis. Journal of Applied Psychology, 80, (6): 652-663.

Fournier, V., \& Grey, C. (2000). At the critical moment: Conditions and prospects for critical management studies. Human Relations, 53, (1): 7-32.

Frerichs, F., \& Naegele, G. (1997). Discrimination of older workers in Germany: Obstacles and options for the integration into employment. Journal of Aging \& Social Policy, 9, (1): 89-101.

Fulcher, J., \& Scott, J. (1999). Sociology. Oxford: Oxford University Press. 
Garnsey, E., \& Rees, B. (1996). Discourse and enactment: Gender inequality in text and context. Human Relations, 49, (8): 1041-1063.

Garsten, C., \& Grey, C. (1997). How to become oneself: Discourses of subjectivity in postbureaucratic organizations. Organization, 4, (2): 211-228.

George, J. (1997). Plenary session. In Making it Work. A Collection of Papers Presented at Making it Work: A Major National Summit on the Future of Work in Australia, May 23 and 24 1996, Melbourne. Fitzroy, Victoria: Brotherhood of St. Laurence. PAGES 45-52.

Gergen, K. J. (1999). An invitation to social construction. London, Thousand Oaks, New Delhi: Sage.

Gergen, K. J. (2001). Social construction in context. London, Thousand Oaks, New Delhi: Sage.

Ginn, J., \& Arber, S. (1995). “Only connect”: Gender relations and ageing. In S. Arber \& J. Ginn (Eds.). Connecting gender and ageing: A sociological approach. Buckingham: Open University Press. PAGES 1-14.

Ginn, J., \& Arber, S. (1996). Patterns of employment, gender and pensions: The effect of work history on older women's non-state pensions. Work, Employment \& Society, 10, (3): 469-490.

Grant, D., Keenoy, T., \& Oswick, C. (1998). Organizational discourse: Of diversity, dichotomy and multi-disciplinarity. In D. Grant, T. Keenoy \& C. Oswick (Eds.). Discourse and organization. London, Sage. PAGES 1-14.

Grant, D., Hardy, C., Oswick, C., \& Putnam, L. (in press). Introduction: Exploring the field of organizational discourse. In D. Grant, C. Hardy, C. Oswick \& L. Putnam (Eds.) Handbook of organizational discourse. London: Sage.

Gullette, M. M. (1997). Declining to decline: Cultural combat and the politics of the midlife. Charlottesville and London: University Press of Virginia.

Hacking, I. (1986). Making up people. In T. C. Heller, M. Sosna \& D. E. Wellbery (Eds.). Reconstructing individualism: Autonomy, individuality, and the self in western thought. Stanford: Stanford University Press. PAGES 222-236.

Hacking, I. (2000). The social construction of what? Cambridge, MA, and London: Harvard University Press.

Hall, S. (1997). The work of representation. In S. Hall (Ed.). Representation: Cultural representations and signifying practices. London: Sage in association with The Open University. PAGES 15-64.

Halliday, M. A. K. (1994). An introduction to functional grammar, $2^{\text {nd }}$ edition. London: Edward Arnold.

Hardy, C. (2004). Scaling up and bearing down in discourse analysis: Questions regarding textual agencies and their context. Organization, 11, (3): 415-425. 
Hardy, C., Lawrence, T., \& Grant, D. (forthcoming). Discourse and collaboration: The role of conversations and collective identity. Academy of Management Review.

Hardy, C., \& Phillips, N. (1999). No joking matter: Discursive struggle in the Canadian refugee system. Organization Studies, 20, (1): 1-24.

Hardy, C., \& Phillips, N. (in press). Discourse and power. In D. Grant, C. Hardy, C. Oswick \& L. Putnam (Eds.). Handbook of organizational discourse. London: Sage.

Hardy, C., Phillips, N., \& Clegg, S. (2001). Reflexivity in social studies: A study of the production of the research subject. Human Relations, 54, (2): 3-32.

Harley, B., \& Hardy, C. (2004). Firing blanks? An analysis of discursive struggle in HRM. Journal of Management Studies, 41, (3): 377-400.

Heracleous, L., \& Barrett M. (2001). Organizational change as discourse: Communicative actions and deep structures in the context of information technology implementation. Academy of Management Journal, 44, (4): 755-78.

Heywood, J. S., Ho, L.-S., \& Wei, X. (1999). The determinants of hiring older workers: Evidence from Hong Kong. Industrial and Labor Relations Review, 52, (3): 444-459.

Hirsch, B., MacPherson, D., \& Hardy, M. (2000). Occupational age structure and access for older workers. Industrial and Labor Relations Review, 53, (3): 401-418.

Howarth, D., \& Stavrakakis, Y. (2000). Introducing discourse theory and political analysis. In D. Howarth, A. J. Norval \& Y. Stavrakakis (Eds.). Discourse theory and political analysis: Identities, hegemonies and social change. Manchester and New York: Manchester University Press. PAGES 1-23.

Huisman, M. (2001). Decision making in meetings as talk-in-interaction. International Studies of Management and Organization, 31, (3): 69-90.

Hutchens, R. M. (1993). Restricted job opportunities and the older worker. In O. S. Mitchell (Ed.). As the workforce ages: Costs, benefits, and policy challenges. Ithaca NY: ILR Press, Cornell University. PAGES 81-102.

Iedema, R., \& Wodak, R. (1999). Introduction: Organizational discourses and practices. Discourse \& Society, 10, (1): 5-19.

Jamieson, A. and Victor, C. (1997). Theory and concepts in social gerontology. In A. Jamieson, S. Harper, and C. Victor (Eds.). Critical Approaches to Ageing and Later Life. Buckingham and Philadelphia: Open University Press. PAGES 175-187.

Jaworski, A., \& Coupland, N. (1999). Introduction: Perspectives on discourse analysis. In A. Jaworski \& N. Coupland (Eds.). The discourse reader. London and New York: Routledge. PAGES 1-44.

Johnson, P., \& Zimmerman, K. F. (1993). Ageing and the European labour market: Public policy issues. In P. Johnson \& K. F. Zimmerman (Eds.). Labour markets in an ageing Europe. Cambridge: Cambridge University Press. PAGES 1-25. 
Katz Olson, L. (1994). Women and social security: A progressive approach. Journal of Aging and Social Policy, 6, (1-2): 43-56.

Keenoy, T., Oswick, C., \& Grant, D. (1997). Organizational discourses: Text and context. Organization, 4, (2): 147-57.

Kenyon, P., \& Wooden, M. (1994). The outlook for labour supply in Australia during the 1990s. Labour Economics and Productivity, 6: 130-55.

Kleiner, B. (1998). The modern racist ideology and its reproduction in "pseudo-argument". Discourse \& Society, 9, (2): 187-215.

Knights, D. (1992). Changing spaces: The disruptive impact of a new epistemological location for the study of management. Academy of Management Review, 17,(3): 514-36.

Knights, D., \& McCabe, D. (2002). A road less travelled: Beyond managerialist, critical and processual approaches to total quality management. Journal of Organizational Change Management, 15, (3): 235-254.

Knights, D., \& Morgan, G. (1991). Strategic discourse and subjectivity: Towards a critical analysis of corporate strategy in organisations. Organization Studies, 12, (3): 251-273.

Kress, G., \& Threadgold, T. (1988). Towards a social theory of genre. Southern Review, 21, (3): 215243.

Laclau, E. (1990). New reflections on the revolution of our time. London: Verso.

Laczko, F., \& Phillipson, C. (1991). Changing work and retirement: Social policy and the older worker. Buckingham: Open University Press.

Langellier, K. M., \& Peterson, E. E. (1993). Family storytelling as a strategy of social control. In D. Mumby (Ed.). Narrative and social control: Critical perspectives. Newbury Park, CA: Sage. PAGES 49-76.

Latimer, J. (1997). Figuring identities, older people, medicine and time. In A. Jamieson, S. Harper and C. Victor (Eds.). Critical Approaches to Ageing and Later Life. Buckingham and Philadelphia: Open University Press. PAGES 143-159.

Latulippe, D., \& Turner, J. (2000). Partial retirement and pension policy in industrialized countries. International Labour Review, 139, (20): 179-195.

Lazear, E. P. (1979). Why is there mandatory retirement? Journal of Political Economy, 87, (6): 12611284.

Leanna, C. R., \& Feldman, D. C. (1992). Coping with job loss: How individuals, organizations, and communities respond to layoffs. New York: Lexington Books.

Levine, M. L. (1988). Age discrimination and the mandatory retirement controversy. Baltimore: The John Hopkins University Press. 
Lim, V. K. G. (2003). An empirical study of older worker attitudes towards the retirement experience. Employee Relations, 25, (4): 330-346.

Lyon, P., \& Glover, I. (1998). Divestment or investment? The contradictions of HRM in relation to older employees. Human Resource Management Journal, 8, (1): 56-66.

McCallum, J. (1990). Australian mandatory retirement challenged. Journal of Aging \& Social Policy, 2, (3-4): 183-200.

McCallum, J. (1992). Asia Pacific retirement: Models for Australia, Fiji, Malaysia, Philippines \& Republic of Korea. Journal of Cross-Cultural Gerontology, 7, (1): 25-43.

McMahan, S., \& Phillips, K. (2000). Aging and employment: Characteristics of those working and retired in California. Journal of Education for Business, 76, (1): 11-18.

Mallier, T., \& Morris, D. (2003). Earnings trends among older employees in England and Wales, 1972-2001. Ageing and Society, 23, (3): 363-374.

Marshak, R. J. (1993). Managing the metaphors of change. Organizational Dynamics, 22, (1): 44-56.

Mauws, M. K. (2000). But is it art? Decision making and discursive resources in the field of cultural production. Journal of Applied Behavioural Science, 36, (2): 229-244.

Meyer, J. W., \& Rowan, B. (1977). Institutionalized organizations: Formal structure as myth and ceremony. American Journal of Sociology, 83: 340-63.

Minkler, M. (1991). Overview. In V. M. Moghadom (ed.). Identity Politics and Women: Cultural Reassertions and Feminisms in International Perspective. Boulder, NY: Westview Press. PAGES 3-26.

Mumby, M. (1997). The problem of hegemony: Rereading Gramsci for organizational communication studies. Western Journal of Communication, 61, (4): 343-375.

Mumby, D. K. (2001). Power and politics. In F. Jablin \& L. L. Putnam (Eds.). The new handbook of organizational communication. Thousand Oaks: Sage. PAGES 585-623.

Mumby, D. K., \& Clair, R. P. (1997). Organizational discourse. In T. A. van Dijk (Ed.). Discourse as social interaction, Discourse studies: A multidisciplinary introduction, Volume 2 (pp. 181-205). London: Sage. PAGES 181-205.

Mumby, D. K., \& Stohl, C. (1991). Power and discourse in organizational studies: Absence and the dialectic of control. Discourse and Society, 2, (3): 313-32.

Murphy, A. G. (1998). Hidden transcripts of flight attendant resistance. Management Communication Quarterly, 11, (4): 499-535

Nilan, P. (1995). Negotiating gendered identity in classroom disputes and collaboration. Discourse \& Society, 6, (1): 27-47. 
Palmer, I., \& Dunford, R. (1996). Conflicting use of metaphors: Reconceptualizing their use in the field of organizational change. Academy of Management Review, 21, (3): 691-717.

Parker, I. (1992). Discourse dynamics. London: Routledge.

Parker, M. (1992). Getting down from the fence: A reply to Haridimos Tsoukas. Organization Studies, 13, (4): 651-654.

Pateman, C. (1989). The disorder of women. Cambridge: Polity Press.

Patrickson, M., \& Hartmann, L. (1996). Older women: Retailing utilizes a neglected workforce resource. Asia Pacific Journal of Human Resources, 34, (2): 88-98.

Pearson, B. (2003, October 25-26). Japan battles an ageing nation. The Weekend Australian Financial Review: 10.

Phillips, L., \& Jørgensen, M. W. (2002). Discourse analysis as theory and method. London: Sage.

Phillips, N., \& Hardy, C. (1997). Managing multiple identities: Discourse, legitimacy and resources in the UK refugee system. Organization, 4, (2): 159-185.

Phillips, N., \& Hardy, C. (2002). Discourse analysis: Investigating processes of social construction. Qualitative Research Methods Series 50. Thousand Oaks, London, New Delhi: Sage

Phillips, N., Hardy, C., \& Lawrence, T. (forthcoming). Discourse and institutions. Academy of Management Review.

Phillipson, C. (1998). Reconstructing Old Age: New Agendas in Social Theory and Practice. London: Sage.

Pickard, J. (1999). Grey areas: retirement and the world's increasingly ageing population. People Mangaement, 5, (15): 30-35.

Pickering, M. (2001). Stereotyping: The politics of representation. Hampshire, UK: Palgrave.

Potter, J., \& Wetherell, M. (1987). Discourse and social psychology: Beyond attitudes and behaviour. London, Thousand Oaks, New Delhi: Sage.

Powers, P. (2001). The methodology of discourse analysis. Boston: Jones and Bartlett.

Purcell, P. J. (2000). Older workers: Employment and retirement trends. Monthly Labor Review, 123, (10): 19-30.

Putnam, L. L., Phillips, N., \& Chapman, P. (1996). Metaphors of communication and organization. In S. R. Clegg, C. Hardy \& W. Nord (Eds.). Handbook of organizational studies. London: Sage. PAGES 375-408. 
Reed, M. (1998). Organizational analysis as discourse analysis: A critique. In D. Grant, T. Keenoy \& C. Oswick (Eds.). Discourse + Organization. London, Thousand Oaks, New Delhi: Sage. PAGES 193-213.

Reid, F. (1996). Abolishing compulsory retirement in Australia: Assessing the impact. Labour, Economics \& Productivity, 8: 25-42.

Rein, M., \& Jacobs, K. (1993). Ageing and employment trends: A comparative analysis for OECD countries. In P. Johnson \& K. F. Zimmerman (Eds.). Labour markets in an ageing Europe. Cambridge: Cambridge University Press. PAGES 53-78.

Rodin, J. (1989). Sense of control: Potentials for intervention. In M. White Riley \& J. R. Riley Jnr. (Eds.). The Annals of the American Academy of Political and Social Science, The Quality of Aging: Strategies for Interventions, 503: 29-42.

Rosen, B. and Jerdee, T. H. (1976a). The nature of job-related age stereotypes. Journal of Applied Psychology, 61, (2): 180-183.

Rosen, B. and Jerdee, T. H. (1976b). The influence of age stereotypes on managerial decision. Journal of Applied Psychology, 61, (4): 428-432.

Ruhm, C. J. (1990). Career jobs, bridge employment, and retirement. In P. Doeringer (Ed.). Bridges to retirement: Older workers in a changing labor market. Ithaca NY: ILR Press, Cornell University. PAGES 92-110.

Saks, A., \& Waldman, D. (1998). The relationship between age and job performance evaluations for entry-level professionals. Journal of Organizational Behaviour, 19, (4): 409-419.

Saunders, P. (1996). Dawning of a new age? The extent, causes and consequences of ageing in Australia. Social Policy Research Centre Discussion Paper, No. 75. Sydney: The University of New South Wales.

Schabracq, M. J. (1994). Training and education programmes for older employees. In J. Snel and R. Cremer (Eds.). Work and aging: A European perspective. London: Taylor and Francis. PAGES 293308.

Schrank, H. T., \& Waring, J. M. (1989). Older workers: Ambivalence and interventions. In M. White Riley \& J. W. Riley Jnr. (Eds.). The Annals of the American Academy of Political and Social Science, The Quality of Aging: Strategies for Interventions, 503: 113-26.

Sheppard, H. L. (1970). Toward an industrial gerontology. In H. L. Sheppard (Ed.). Toward an industrial gerontology: An introduction to a new field of applied research and service. Cambridge MA: Schenkman Publishing Company. PAGES 1-11.

Snape, E., \& Redman, T. (2003). Too old or too young? The impact of perceived age discrimination. Human Resource Management Journal, 13, (1): 78-89.

Staudinger, U. M., Cornelius, S. W., \& Baltes, P. B. (1989). The aging of intelligence: Potential and limits. In M. White Riley \& J. W. Riley Jnr. (Eds.). The Annals of the American Academy of Political and Social Science, The Quality of Aging: Strategies for Interventions, 503: 43-112. 
Stephenson, P. H., Wolfe, N. K., Coughlan, R., \& Koehn, S. D. (1999). A methodological discourse on gender, independence and frailty: Applied dimensions of identity construction in old age. Journal of Aging Studies, 13, (4): 391-401.

Sterns, H., \& Doverspike, D. (1989). Aging and the training and learning process. In I. Goldstein (Ed.). Training and development in organizations. San Francisco: Jossey Bass. PAGES 57-69.

Stokoe, E. H. (1998). Talking about gender: The conversational construction of gender categories in academic discourse. Discourse \& Society, 9, (2): 117-140.

Sum, A. M., \& Fogg, W. N. (1990a). Labor market and poverty problems of older workers and their families. In P. Doeringer (Ed.). Bridges to retirement: Older workers in a changing labor market. Ithaca NY: ILR Press, Cornell University. PAGES 64-91.

Sum, A. M., \& Fogg, W. N. (1990b). Profile of the labor market for older workers. In P. Doeringer (Ed.). Bridges to retirement: Older workers in a changing labor market. Ithaca NY: ILR Press, Cornell University. PAGES 33-63.

Tannen, D. (1994). Gender and discourse. New York and Oxford: Oxford University Press.

Tannen, D. (1995). The power of talk: Who gets heard and why. Harvard Business Review, 74, (5): 138-148.

Taylor, J. R., Cooren, F., Giroux, N., \& Robichaud, D. (1996). The communicational basis of organization: Between the conversation and the text. Communication Theory, 6, (1): 1-39.

Taylor, J. R., \& Van Every, E. J. (1993). The vulnerable fortress: Bureaucratic organization in the information age. Toronto: University of Toronto.

Taylor, P., \& Walker, A. (1998). Policies and practices towards older workers: A framework for comparative research. Human Resource Management Journal, 8, (3): 61-76.

Teiger, C. (1994). We are all aging workers: For an interdisciplinary approach to aging at work. In J. Snel \& R. Cremer (Eds.). Work and aging: A European perspective. London: Taylor and Francis. PAGES 65-84.

Thibault, P. (1991). Social semiotics as praxis. Minnesota: University of Minnesota Press.

Thompson, P. (1993). Postmodernism - Fatal distraction. In J. Hassard \& M. Parker (Eds.). Postmodernism and organizations. London: Sage. PAGES 183-203.

Thompson, P. (forthcoming). Brands, boundaries and bandwagons: A critical reflection on critical management studies. In S. Fleetwood and S. Ackroyd (Eds.). Critical realism in action in organisation and management studies. London: Routledge.

Townley, B. (1993). Foucault, power/knowledge and its relevance for human resource management. Academy of Management Review, 18, (3): 518-545. 
Tretheway, A. (1999). Disciplined bodies: Women's embodied identities at work. Organization Studies, 20, (3): 423-450.

Tretheway, A. (2001). Reproducing and resisting the master narrative of decline. Management Communication Quarterly, 15, (2): 183-226.

Tsoukas, H. (1992). Postmodernism, reflective rationalism and organization studies: A reply to Martin Parker. Organization Studies, 13, (4): 643-650.

Tulle-Winton, E. (1999). Growing old and resistance: Towards a new cultural economy of old age? Ageing and Society, 19, (3): 281-99.

VandenHeuvel, A. (1999). Older workers: How do they fare in today's labour market. Paper presented to inaugural National Council on the Aging Congress, Older Australians: A working future? Adelaide, 7-9 November.

Van Dijk, T. (1997a). The study of discourse. In T. A. van Dijk (Ed.). Discourse as social structure, Discourse studies: A multidisciplinary introduction, Volume 1. London: Sage. PAGES 1-34.

Van Dijk, T. (1997b). Discourse as interaction in society. In T. A. van Dijk (Ed.). Discourse as social interaction, Discourse studies: A multidisciplinary introduction, Volume 2. London: Sage. PAGES 137

Van Dijk, T. (1997c). Political discourse and racism: Describing others in Western parliaments. In S. H. Riggins (Ed.). The language and politics of exclusion. Thousand Oaks: Sage. PAGES 31-64.

Van Dijk, T. (1991). Racism and the press. London: Routledge.

Van Dijk T., Ting-Toomey S., Smitherman G., \& Troutman D. (1997). Discourse, ethnicity, culture and racism. In T. A. van Dijk (Ed.). Discourse as social interaction, Discourse studies: A multidisciplinary introduction, Volume 2. London: Sage. PAGES 144-180.

Warr, P. (1994). Age and job performance. In J. Snel \& R. Cremer (Eds.). Work and aging: A European perspective. London: Taylor and Francis. PAGES 309-322.

Warren, C. A. B. (1998). Aging and identity in premodern times. Research on Aging, 20, (1): 11-35.

Watson, D., \& Shael, A. (1997). Older workers: Myths and realities: A study of the perceptions of employment of older workers in the western region of Melbourne. Melbourne: Victoria University of Technology Press.

Weedon, C. (1999). Feminism, theory and the politics of difference. Oxford: Blackwell.

West, C., Lazar, M. M., \& Kramarae, C. (1997). Gender in discourse. In T. A. van Dijk (Ed.). Discourse as social interaction, Discourse studies: A multidisciplinary introduction, Volume 2. London: Sage. PAGES 119-143.

Wetherell, M. (2001). Minds, selves and sense-making: Editor's introduction. In M. Wetherell, S. Taylor \& S. J. Yates (Eds.). Discourse theory and practice: A reader. London: Sage in association with The Open University. PAGES 186-197. 
White Riley, M., \& Riley, J. W. Jnr. (1989). The lives of older people and changing social roles. In M. White Riley and J. W. Riley Jnr. (Eds.). The Annals of the American Academy of Political and Social Science, The Quality of Aging: Strategies for Interventions, 503: 14-28.

Witten, M. (1993). Narrative and the culture of obedience at the workplace. In D. Mumby (Ed.). Narrative and social control: Critical perspectives. Newbury Park, CA: Sage. PAGES 97-118.

Wodak, R. (1996). The genesis of racist discourse in Austria since 1989. In C. R. Caldas-Coulthard \& M. Coulthard (Eds.). Texts and practices: Readings in critical discourse analysis. London: Routledge. PAGES 107-128.

Wodak, R. (1997). Das Ausland and anti-semitic discourse: The discursive construction of the other. In S. H. Riggins (Ed.). The language and politics of exclusion. Thousand Oaks: Sage. PAGES 65-87.

Wodak, R., \& Matouschek, B. (1993). "We are dealing with people whose origins one can clearly tell just by looking”: Critical discourse analysis and the study of neo-racism in contemporary Austria. Discourse \& Society, 4, (2): 225-248.

Wood, L. A., \& Kroger, R. O. (2000). Doing discourse analysis: Methods for studying action in talk and text. Thousand Oaks, London, New Delhi: Sage.

Yeung, L. (1997). Confrontation or resolution: Discourse strategies for dealing with conflicts in participative decision-making. Journal of Applied Management Studies, 6, (1): 63-75.

Ylanne-McEwen, V. (2000). Golden times for golden-agers: Selling holidays as lifestyle for the over 50s'. Journal of Communication, 50, (3): 83-99. 


\section{Notes}

\footnotetext{
${ }^{1}$ We include a discussion of the older unemployed worker under the category of older worker.

${ }^{2}$ We use these broad, descriptive categories for presentational and analytical purposes - we acknowledge that research often cuts across different research traditions and cannot always be neatly categorized.

${ }^{3}$ For example, at the most simplistic level, there is divergence regarding the age of the older worker. In economic research, people over 65 are considered to be in the older age group and part of the dependent nonproductive population. In labour market research, older workers have been variously defined as those over 55, 45 and, sometimes, 40 years. Some qualitative research, on the other hand, argues that the category applies when older age is experienced, which can lower the age limit further, especially in the case of women (Ginn and Arber 1995; Encel 1995).

${ }^{4}$ This does not deny that discourse analysis has been used to promulgate a variety of other perspectives, including positivism (Grant et al, 2004). Such work sees discourse as a communicative practice that can be empirically examined to determine is meaning in functional terms (Putnam et al., 1996). According to this view, discourse is a tool "at actors' disposal, emphasising the purposive and instrumental use of such communicative actions for the facilitation of managerially relevant processes and outcomes” (Heracleous and Barrett, 2001: 756). Such studies use empirically derived data to identify patterns and regularities within the discursive interactions of various organizational actors (e.g., Brown, 1985; Crouch and Basch, 1997; Donnellon, 1994; Huisman, 2001; Marshak, 1993; Palmer and Dunford, 1996; Tannen, 1995; Yeung, 1997).

${ }^{5}$ Such an idea is not recent - writing in the early twentieth century, Mead (1982) argued that identities only emerge in social life and under social conditions, rather than being inherent to the individual. Mead viewed language as having a critical role in this process because it was the means by which people internalized the values and beliefs of their social groups and thus formed their own social identities (Burkitt 1991).
} 


\section{University Library}

\section{- M M I N E R VA A gateway to Melbourne's research publications}

Minerva Access is the Institutional Repository of The University of Melbourne

Author/s:

Ainsworth, S; Hardy, C

Title:

Critical discourse analysis and identity: why bother?

Date:

2004-10

Citation:

Ainsworth, S. \& Hardy, C. (2004). Critical discourse analysis and identity: why bother?. Critical Discourse Studies, 1 (2), pp.225-259. https:// doi.org/10.1080/1740590042000302085.

Persistent Link:

http://hdl.handle.net/11343/116077 